Penelitian

\title{
Bacterial Pneumonia sebagai Salah Satu Penyebab Kematian Lumba Lumba Hidung Botol Indo-Pasifik (Tursiop aduncus)
}

\author{
Bacterial Pneumonia as one of the causes of death of \\ Indo-Pacific bottlenose dolphins (Tursiop aduncus)
}

\author{
Agustin indrawati ${ }^{i^{*}}$, Jeni Maharani ${ }^{2}$, Nurul Fadillah ${ }^{2}$, Diah Sekar Arum², Hamdika Yenri', \\ Risqika A Velayati ${ }^{2}$, Ulfi Nurul Fadilah ${ }^{2}$, Jefri Naldi ${ }^{2}$, Afifah Nurhasanah ${ }^{2}$ \\ 'Divisi Mikrobiologi Medik, Departemen Ilmu Penyakit Hewan dan Kesmavet \\ ${ }^{2}$ Program Pendidikan Profesi Dokter Hewan. \\ Fakultas Kedokteran Hewan, Institut Pertanian Bogor, Fakultas Kedokteran Hewan, \\ Institut Pertanian Bogor, Jln Agatis Kampus Darmaga Bogor,16880 \\ *Penulis untuk korespondensi: titin.seta@gmail.com \\ Diterima 11 April 2020, Disetujui 20Juni 2020
}

\begin{abstract}
ABSTRAK
Lumba-lumba hidung botol Indo-Pasifik (Tursiops aduncus) merupakan jenis lumba-lumba yang banyak ditemukan di perairan Indonesia. Kelestarian $T$. aduncus perlu mendapat perhatian karena populasinya yang semakin menurun. Upaya pelestarian yang telah dilakukan adalah melalui konservasi. Gangguan respirasi pada lumba-lumba sering ditemukan dan berakibat fatal, salah satu penyakit yang sering ditemukan adalah pneumonia. Pneumonia jenis bronchopneumonia merupakan salah satu gejala infeksi pada paru yang disebabkan oleh bakteri, virus ataupun jamur. Tujuan penelitian ini adalah melakukan isolasi dan identifikasi bakteri yang berperan dalam kejadian pneumonia. Sampel berasal dari seekor lumba lumba jantan yang ada di Pusat Konservasi Mamalia air. Tahapan penelitianini antara lain isolasi dan identifikasi bakteri dari organ paru-paru yang menunjukkan gejala patologis. Hasil isolasi dan identifikasi ditemukan 2 spesies Gram positif yaitu Staphylococcus epidermidis dan Staphylococcus aureus serta 4 spesies Gram negatif, yaitu Pseudomonas alcaligenes, Actinobacillus delphinicola, Klebsiella sp. dan Serratia marcesens.
\end{abstract}

Kata kunci: bakteri, bronchopneumonia, Indonesia, Konservasi, Tursiopaduncus

\begin{abstract}
The Indo-Pacific bottlenose dolphin (Tursiops aduncus) is a common dolphin that can be found in Indonesian marine territory. The sustainability of $T$. aduncus must be considered carefully because of its declining population. One effort in protecting rare species is through conservation. Respiratory disorders in dolphins are often found and fatal, one of the most common disease found in dolphin is pneumonia. Pneumonia is one of the symptoms of lung infection caused by bacteria, viruses or fungi. The purpose of this study is to isolate and identify bacteria which play a role in the occurence of pneumonia. The sample obtained from a male dolphin in the Water Mammal Conservation Center. In this study, isolation and identification of bacteria from the lung organs were carried out from dolphin that showed pathological symptoms. The results of isolation and identification found 2 positive Gram species, Staphylococcus epidermidis and Staphylococcus aureus also 4 negative Gram species. The four negative Gram bacteria were Pseudomonas alcaligenes, Actinobacillus delphinicola, Klebsiella sp. and Serratia marcesens.
\end{abstract}

Keywords: bacteria, bronchopneumonia, Conservation, Indonesia, Tursiop aduncus 


\section{PENDAHULUAN}

Mamalia laut merupakan salah satu anggota kelas mamalia yang telah beradaptasi untuk hidup di dalam air. Salah satu mamalia laut yang banyak ditemukan di laut Indonesia adalah ordo Cetacea yang meliputi paus, lumba-lumba dan dugong. Ordo Cetacea banyak tersebar di seluruh perairan pantai hingga laut dalam, baik yang berhabitat menetap maupun yang bermigrasi. Lebih dari 40 jenis lumbalumba yang terbagi dalam 17 genus yang terdapat di seluruh dunia. Jenis lumba-lumba yang paling banyak jumlahnya dan memiliki distribusi yang luas adalah lumba-lumba hidung botol (Tursiops sp.).

Lumba-lumba hidung botol Indo-Pasifik (T. aduncus) merupakan salah satu lumba-lumba yang banyak ditemukan di perairan Indonesia. Berkaitan dengan status populasi T. aduncus di Indonesia yang semakin berkurang, maka diperlukan pengelolaan kesehatan untuk menjaga populasi lumba-lumba tersebut dapat tetap terjaga. Upaya pengelolaan yang dapat dilakukan adalah melalui konservasi sumber daya alam serta konservasi medis, meliputi manajemen kesehatan, reproduksi, pemeliharaan satwa. Salah satu informasi yang diperlukan agar upaya konservasi terhadap T. aduncus berhasil antara lain mengenai manajemen kesehatan satwa yang berkaitan dengan penyakit dan agen-agen penyebabnya.

Penelitian tentang keberadaan bakteri, virus, protozoa, atau cendawan sebagai mikrofloranormal maupun mikroorganisme patogen pada $T$. aduncus belum banyak dilakukan di Indonesia. Hal ini dibuktikan dengan masih sedikitnya informasi yang berhubungan dengan masalah penyakit yang disebabkan oleh agen infeksius pada T. aduncus. Penyakit respirasi akibat infeksi bakteri sering kali terjadi pada T. aduncus. Bakteri patogen penyebab pneumonia pernah ditemukan pada lumba-lumba hidung botol atlantis (Tursiop truncatus) diantaranya adalah bakteri Aeromonas hydrophila, Pseudomonas aeruginosa, Staphylococcus aureus, Streptococcus grup D dan Erysipelothrix rhusiopathiae (Stephanie el al., 2012). Menurut Higgins (2000), di dalam saluran pernafasan lumba lumba $T$. truncatus ditemukan adanya bermacam macam bakteri diantaranya A. hydrophyla, Vibrio alginolyticus, Mycobacterium spp., Nocardia asterioides, Nocardia brasiliensis dan S. aureus. Morris et al. (2011) juga melaporkan bahwa jenis Bacillus sp. merupakan jenis bakteri yang umum ditemukan pada blowhole dan lambung $T$. truncatus di perairan laut tenggara Amerika Serikat.
Penelitian yang dilakukan oleh Rini et al., (2012) menemukan adanya beberapa bakteri asal blowhole yang diisolasi dari 11 ekor T. aduncus sehat. Bakteri yang ditemukan tersebut adalah Pseudomonas sp., Moraxella sp., Yersinia sp., Bacillus sp., Citrobacter sp., Klebsiella sp., S. aureus, S. epidermidis, Pasteurella sp., dan Actinobacillus sp.. Pneumonia merupakan penyakit umum yang menyebabkan morbiditas tinggi pada lumba-lumba hidung botol (Watson et al., 2012). Penelitian in bertujuan untuk melakukan identifikasi bakteriyang sering berperan terjadinya bronchopneumonia sebagai penyebab kematian pada lumba-lumba.

\section{BAHAN DAN METODE}

\section{Sampel}

Bahan yang digunakan dalam penelitian ini adalah sampel organ paru paru yang diperoleh dari Lembaga Konservasi Mamalia Air PT. Wersut Seguni Indonesia (PT. WSI). Nekropsi dilakukan setelah lumba lumba ditemukan mati . Organ paru paru yang menunjukkan gejala pneumonia diambil secara aseptik dan dikoleksi untuk dilakukan pemeriksaan mikrobiologis.

\section{Isolasi dan Identifikasi}

Sampel organ paru-paru dibiakkan pada media media blood agar (BA), media MacConkay agar (MCA). Koloni bakteri tunggal yang diduga sebagai penyebab pneumonia disuburkan dengan menggunakan media tryptic soy agar (TSA). Koloni diamati secara makroskopis dan mikroskopis dengan menggunakan pewarnaan Gram untuk melihat morfologi, sifat Gram dan kemurnian. Koloni terduga kemudian disuburkan pada media TSA dan diinkubasi pada suhu $37^{\circ} \mathrm{C}$ selama 24 jam.

\section{Identifikasi Bakteri}

Identifikasidilakukan setelah koloni bakteri dinyatakan murni dan hasil pewamaan sudah dilakukan dan menunjukkan hasil apakah bakteri termasuk bakteri Gram positifatau Gram Negatif. Identifikasi mengacu pada metode isolasi dan identifikasi bakteri (Capuccino \& Sherman, 2008). Pengujian untuk bakteri Gram positif antara lain uji katalase, uji fermentasi glukosa aerobik dan mikroaerofilikserta uji pertumbuhan bakteri pada media MSA dan uji koagulase. Pengujian yang dilakukan untukbakteri Gram negatif antara lain uji Indol, motilitas, MR-VP, Sitrat, Urea, TSIA dan uji fermentasi karbohidrat. 


\section{HASIL}

Pneumonia merupakan salah satu gejala penyakit yang sering ditemukan pada lumba lumba dengan angka morbiditasnya cukup tinggi. Kasus pneumonia di pusat konservasi Mamalia air PT WSI dengan kondisi ringan berhasil disembuhkan dengan pemberian antibiotika gologan kuinolon dan tetrasiklin serta multivitamin (Vitamin C, Vitamin A dan Hemaviton). Lumba-lumba yang menderita pneumonia dalam waktu cukup lama, yaitu selama 2 bulan menunjukkan gejala susah bernafas, batuk, sering berenang dipermukaan kolam dalam posisi vertikal dan mengeluarkan lendir dari lubang pernafasan (blowhole). Pengobatan yang diberikan selama lumba-lumba menunjukkan gejala antara lain dengan pemberian antibiotik gentamicin, azithromycin dan amikacin selama 3 bulan serta pemberian multivitamin (Lai et al., 2016).

Lumba-lumba yang tidak menujukkan perubahan selama pengobatan mengalami kematian. Organ yang menunjukkan perubahan patologi anatomi diambil setelah dinekropsi. Organ yang diambil antara lain paru-paru yang mengalami abses dan haemoragi. Menurut Yeon \& Kwon(2011), pneumonia merupakan salah satu gejala yang sering muncul pada ordo Cetacea dan dengan gejala awal yang terlihat adalah adanya nafsu makan yang menurun (anoreksia).

Identifikasi bakteri pada sampel paru-paru menunjukkan adanya bakteri Gramnegatif dan bakteri Gram positif. Berdasarkan hasil identifikasi menurut Capucino \& Sherman (2008) dan Barrow \& Feltham (1992), baik secara mikroskopik maupun berdasarkan uji biokimia. ditemukan 6 spesies bakteri, dua bakteri termasuk dalam bakteri Gram positif yaitu S. epidermidis dan S. aureus. Bakteri Gram negatif yang teridentifikasi adalah $P$. alcaligenes, $A$. delphinicola, Klebsiella sp. dan S. marcesens (Gambar1).

\section{PEMBAHASAN}

Staphyylococcus epidermidis adalah bakteri Gram positif bentuk kokus, mampu menghasilkan enzim katalase dan tidak memfermentasi manitol. Bakteri ini banyak ditemukan pada manusia dan hewan dan merupakan flora normal. Menurut Quinn et al., (2004), S. epidermidis dapat berperan sebagai patogen oportunistik ketika sistem imunitas sedang turun. Bakteri ini banyak ditemukan di lingkungan

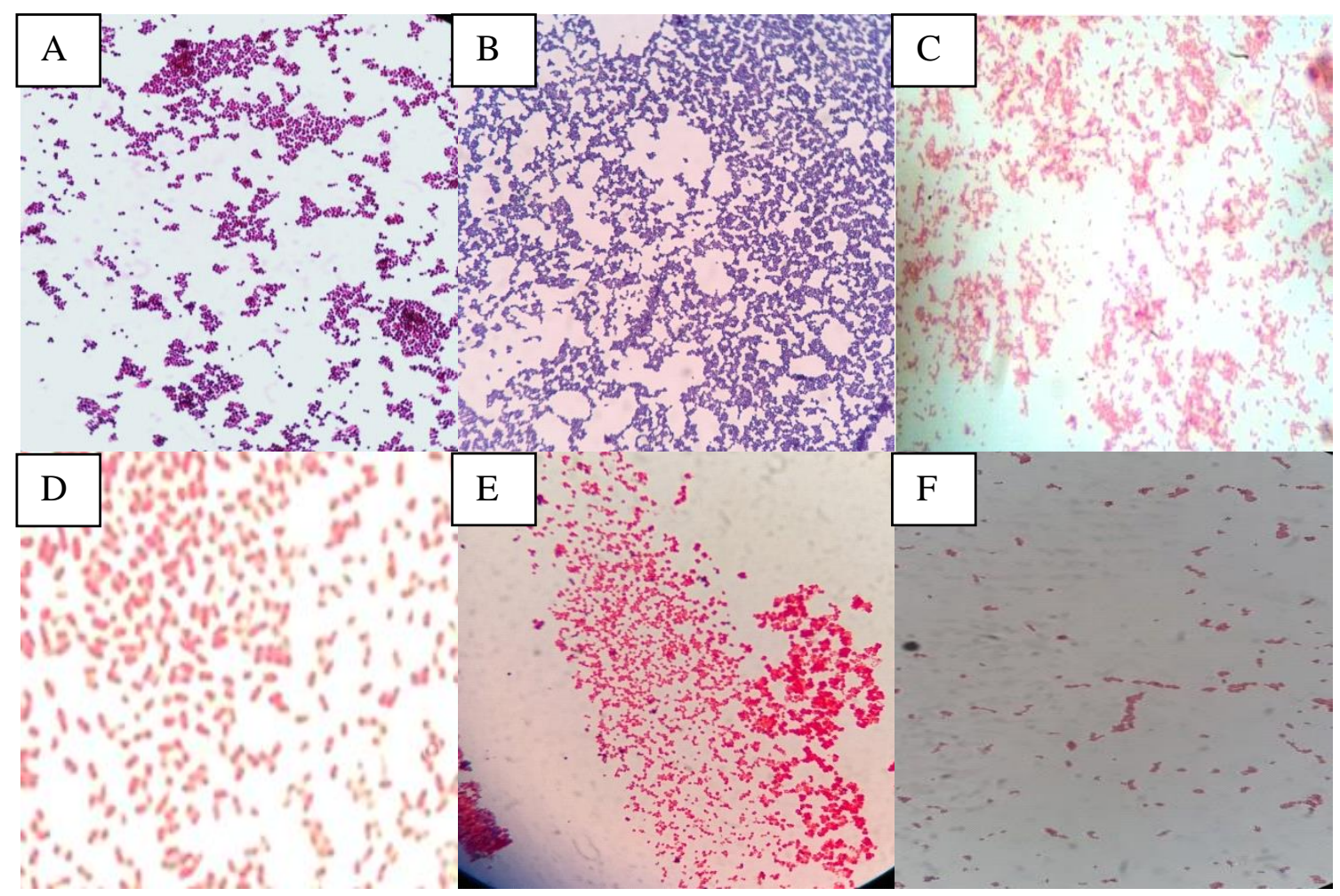

Gambar 1 Gambaran mikroskopik bakteri yang diisolasi dari sampel paru-paru lumba-lumba (Perbesaran 1000x). Keterangan: A: Staphylococcus epidermidis; B: Staphylococcus aureus; C: Pseudomonas alcaligenes; D: Klebsiella sp; E: Actinobacillus delphinicola; F: Serratia marcesens 
baik di tanah, air, dan udara. Higgins (2000) menyatakan bahwa beberapa jenis Staphylococcus sering ditemukan pada sistem organ tubuh dari T. truncatus, yaitu S. aureus, S. delphini, S. epidermidis, dan S. hyicus. Bakteri-bakteri ini sering ditemukan di sistem integumen, pernafasan, pencernaan, dan urogenital serta pada blowhole. Menurut Dunn et al., (2001) S. epidermidis ditemukan pada $T$. truncatus yang menunjukkangejala klinis kesulitan pernafasan dan batuk.

Staphylococcus aureus adalah bakteri Gram positif, bersifat anaerob fakultatif, katalase positif, oksidase negatif, koagulase positif, dan tidak motil serta bersifat patogen pada hewan dan manusia. Bakteri Gram positif ini tidak dapat tumbuh pada media agar MacConkey karena kandungan garam empedu yang ada dalam media tersebut, namun dapat tumbuh dengan baik pada media agar darah dan nutrient agar. Koloni dari S.aureus dapat ditemukan pada saluran pernafasan, kulit, membran mukosa, dan saluran pencernaan lumba-lumba. $S$. aureus merupakan mikroflora normal didalam tubuh lumba-lumba hidung botol atlantik ( $T$. truncatus) yang hidup liar. Bakteri ini akan berubah menjadi patogen ketika hewan mengalami stress, imunosupresi ataupun dalam pengobatan antimikrobial tertentu. Banyak kematian lumba-lumba dilaporkan karena pneumonia oleh S. aureus (Carol et al., 1991). S. aureus juga dilaporkan diisolasi dari lumba-lumba sebagai mikrobiota normal maupun dari paru-paru lumba-lumba yang memiliki gejala klinis bronkopneumonia. (Streitfeld \& Chapman, 1976). S.aureus juga sering menyerang saluran pernafasan dan menyebabkan pneumonia pada lumba-lumba (Yeon Eo \& Kwon, 2011), dan telah diidentifikasi sebagai patogen berisiko tinggi bagi kesehatan Cetacea (Watson et al., 2008). Penelitian di San Diego menunjukkan bahwa S. aureus merupakan bakteri yang paling sering ditemukan pada kasus pneumonia di lumbalumba (Watson et al., 2012). S. aureus dianggap sebagai mikroflora normal pada $T$. truncatus yang berada di penangkaran atau yang hidup bebas (Streitfeld \& Chapman, 1976).

Actinobacillus delphinicola adalah bakteri Gram negatif berbentuk batang ataupun kokoid yang termasuk ke dalam famili Pasteurellaceae. Bakteri ini bersifat tidak motil, dan tidak berspora, namun mampu untuk memfermentasikan karbohidrat dan tidak menghasilkan gas (Quinn et al. 2004). A. delphinicola mampu memfermentasikan glukosa dan laktosa dan atau sukrosa pada media TSIA. Selain itu, bakteri ini tidak tumbuh pada media MCA disuhu $22^{\circ} \mathrm{C}$, tetapiakan tumbuh disuhu $30-42^{\circ} \mathrm{C}$. Hal tersebut sejalan dengan uji, hasil uji TSIA positif namun tidak ada gas $\mathrm{H}_{2} \mathrm{~S}$, serta bakteri ini tumbuh di media MCA ketika diinkubasi pada suhu $37^{\circ} \mathrm{C}$. A. delphinicola jarang ditemukan pada mamalia laut lain selain dari ordo Cetacea (Foster et al. 1996). A. delphinicola merupakan jenis bakteri baru yang berhasil diidentifikasi pada tahun 1996. A. delphinicola berhasil diisolasi dari beberapa jaringan tubuh lumba-lumba belang (Stenella coeruleoalba) dan lumba-lumba dermaga (Phocoena phocoena). Bagian tubuh yang diisolasi yaitu jaringan paru-paru, serviks, uterus, intestinal, dan limfonodus mandibular. A. delphinicola merupakan bakteriyang menginfeksi namun tidak menimbulkan gejala patologis yang jelas (Foster et al., 1996).

Serratia marcescens merupakan salah satu bakteri Gram negatif yang paling banyak ditemukan di air selain Serratia liquefaciens (Grimont \& Grimont 2006). Beberapa spesies Serratia sp. yang pernah ditemukan pada T. truncatus yaitu Serratia sp. dari anus dan lesio kulit, S. liquefaciens dari blowhole dan paru-paru, dan Serratia rubidaea dari paru-paru dan blowhole (Buck et al., 1991; Morris et al., 2011). S. marcescens secara optimal tumbuh pada suhu $37^{\circ} \mathrm{C}$, tetapi juga bisa tumbuh dalam suhu berkisar dari 5 hingga $40{ }^{\circ} \mathrm{C}$ (Tanaka et al., 2004). Bakteri ini tumbuh dalam tingkat $\mathrm{pH} 5$ hingga 9. S. marcescens adalah bakteri gram negatif yang memiliki pigmentasi merah yang disebut prodigiosin. Bakteri ini termasuk kedalam mikroorganisme patogen yang dapat mengakibatkan infeksi saluran pernapasan, infeksi saluran kemih, septikemia, meningitis. Beberapa kasus yang telah dilaporkan pada mamalia darat Serratia sp. dapat menyebabkan septikemia pada anak kuda, babi, dan kambing, keratokonjungtivitis pada kuda; dan aborsi pada sapi (Grimont \& Grimont, 2006) sehingga mungkin hal tersebut juga dapat terjadi pada mamalia laut termasuk T. aduncus.

Pseudomonas alcaligenes merupakan bakteri Gram negatif, berbentuk batang, bersifat motil, memiliki hasil uji indol negatif, uji urea negatif, dan uji sitrat positif. Bakteri ini tidak dapat memfermentasikan sebagian besar karbohidrat seperti glukosa, fruktosa, manitol, maltosa, dan sukrosa (Barrow \& Feltham 1993; Procop et al., 2017). Pseudomonas adalah kelompok bakteri yang sering ditemukan pada blowhole lumba-lumba. Bakteri ini sering ditemukan pada blowhole lumba-lumba kemungkinan karena keberadaannya yang tersebarluas di lingkungan Morris et al., (2011)yang melakukan penelitian terhadap 
180 ekor $T$. truncatus di perairan laut tenggara Amerika Serikat menyebutkan bahwa salah satu bakteri yang banyak ditemukan adalah Pseudomonas sp. seperti, $P$. aeruginosa, $P$. alcaligenes, $P$. fluorescens, dan $P$. stutzeri. Pseudomonas sp. merupakan salah satu agen patogen penyebab pneumoniayang sering ditemukan pada lumba-lumba hidung botol di perairan Amerika. Pseudomonas sp. juga dilaporkan pernah diisolasi dari lumba-lumba yang mengalami bronkopneumonia akut (Frances et al., 2018). Selain ditemukan pada saluran pernapasan, bakteri ini juga dapat diisolasi dari kulit, saluran perncernaan, dan saluran genital lumba-lumba dan hewan mamalia laut lain, seperti paus, singa laut, dan anjing laut (Higgins 2000).

Klebsiella sp. merupakan bakteri Gram negatif berbentuk kokoid, tidak motil dan memfermentasi glukosa, sukrosa dan laktosa. $K$ pneumonie dapat ditemukan pada sistem pernafasan dan pencernaan lumba-lumba, singa laut california, dan paus putih atau beluga (Higgins, 2000). K. pneumonie dapat ditemukan pada cairan amnion Irawadi Dolpin yang mati karena gangguan respirasi (Yu \& Xia, 2013). K. pneumonie juga berhasil diisolasi dari blowhole, anus, dan lambung $T$. truncatus di perairan laut tenggara Amerika Serikat (Morris et al., 2011). Klebsiella sp. merupakan salah satu jenis bakteri yang dapat menyebabkan terjadinya pneumonia dan kematian pada lumba-lumba. Keberadaan bakteri ini di dalam tubuh lumba-lumba cukup mendapat perhatian khusus, karena selain patogen itasnya yang tinggi dikh awatirkan lumba-lumbayang terinfeksi bakteri ini dapat menjadi karier atau agen pembawa yang dapat menyebabkan infeksi pada lumba-lumba lain (Buck et al., 2006; Tellez et al., 2010).

Kematian lumba lumba akibat bacterial pneumonia sering ditemukan dan $25 \%$ kejadian kasus kematian pada lumba lumba amazone adalah akibat pneumonia disamping akibat penyakit yang lain (Rodrigues et al., 2018). Bakteri patogen disamping itu juga merupakan suatu infeksi sekunder yang mengikuti infeksi akibat penyakit lain diantaranya akibat infeksi virus, infeksi yang bersifat sistemik, sistem kekebalan yang terganggu ataupun pengaruh lingkungan hidupnya. Stres merupakan salah satu penyebab terjadinya infeksi saluran respirasi dengan tanda tanda nafsu makan menurun, laju pernafasan meningkat, batuk dan keluar bau dari blowhole. Menurut Yeon Eo \& Kwon (2011) terjadi kematian pada 2 ekor Lumba lumba Tursiop truncatus di kebun binatang Korea diakibatkan oleh infeksi S. aureus dan P. aeroginosa yang menyebabkan terjadinya septicemia. Kematian akibat bakteri lain juga ditemukan pada Irawadi dolphin (Orcaella brevirostris) akibat bacterial pneumonia (Yu \& Xia, 2013).

Dugaan pneumonia sebagai penyebab kematian lumba-lumba di Lembaga Konservasi Mamalia Air PT WSI adalah akibat infeksi bakteri Klebsiella sp dan Pseudomonas alcaligenes. Bakteri pathogen lain berfungsi memperberat kejadian penyakit. Masingmasing bakteri yang ditemukan kemungkinan ada yang menginfeksi bersamaan tetapi ada juga bakteri yang baru mulai menginfeksi setelah adanya stres ataupun saat sistem kekebalan mulai menurun seperti Staphylococcus epidermidis, Staphylococcus aureus dan Serratia marcesens

Pneumonia yang menyebabkan terjadinya kematian lumba lumba hidung botol (Tursiop aduncus) di Lembaga Konservasi Mamalia Air PT. WSI merupakan bacterial pneumonia yang disebabkan oleh beberapa bakteri patogen. Bakteri tersebut terdiri dari bakteri Gram positif Staphylococcus epidermidis, Staphylococcus aureus, dan bakteri Gram negatif Pseudomonas alcaligenes, Actinobacillus delphinicola, Klebsiella sp dan Serratia marcesens.

\section{UCAPAN TERIMA KASIH}

Penulis mengucapkan terima kasih kepada PT Wersut Seguni Indonesia yang telah memperbolehkan pengambilan sampel saat lumba -lumba dilakukan nekropsi.

"Penulis menyatakan tidak ada konflik kepentingan dengan pihak-pihak yang terkait dalam penelitian ini".

\section{DAFTAR PUSTAKA}

Barrow GI, Feltham RKA. 1993. Cowan and Steel's Manual for Identification of Medical Bacteria. Ed ke-3. Cambridge (UK): Cambridge University Pr.

Buck JD, Overstrom NA, Patton GW, Anderson HF, Gorzelany JF. 1991. Bacteria associated with stranded Cetaceans from the northeast USA and southwest Florida Gulf coasts. Dis Aquat Org. 10: 147-152.

Buck JD, Randall SW, Howard LR, Larry JH. 2006. Aerobic microorganisms associated with freeranging bottlenose dolphins in coastal gulf of mexico and atlantic ocean waters. Journal of Wildlife Diseases, 42(3), 2006, pp. 536-544. 
Capuccino JG, Sherman N. 2008. Microbiology : a Laboratory Mannual. The Pearson International Edition.

Carol JP, Peter S, Roger S, Fujioka, James TD. 1991. Staphylococcus aureus Infection in Newly Captured Pasific bottlenose Dolphins (Tursiops truncates gilli). Journal of Zoo and Wildlife Medicine. $22(3): 330-338$

Dunn JL, Buck JD, Robeck TR. 2001. Bacterial Diseases of Cetaceans and Pinnipeds. Di dalam: Dierauf LA, Gulland FMD, editor. Marine Mammal Medicine. Ed ke-2. Florida: CRC Press.

Forrest MG, Shannon MW, Lara SG, Jenny MM, Cynthia RS, Eric DJ. 2016. Klebsiella pneumoniaeAssociated Meningitis and Septicemia in a Neonatal Bottlenose Dolphin (Tursiops truncatus). International Association for Aquatic Animal Medicine, 47th Annual IAAAM meeting and conference.

Foster G, Ross HM, Malnick H. 1996. Actinobacillus delphinicola: a new member of the family Pasteurellaceae isolated from sea mammals. International Journal Systematic Bacteriology. 46(1): 648-652.

Frances MDG, Dierauf LA, Whitman KL. 2018. CRC Handbook of Marine Mammal Medicine. 3rd ed. Boca Raton (US): CRC Pr.

Grimont F, Grimont PAD. 2006. The genus Serratia. Prokaryotes. Journal of Veterinary Microbiology. 6: 219-244.

Higgins R. 2000. Bacteria and fungi of marine mammals: A Review. Journal Canadian Veterinary. 41(1):105-116.

Lai FL, Jen IF, Chang EH. 2016. Successful treatment of Pseudomonas aeruginosa bronchopneumonia in a captive pacific bottlenose dolphin (Tursiops truncates gilli) with lung abscess. IAAAM. 2016: 1-2.

Marshall CD. 2002. Morphology in Encyclopedia of Marine Mammals. W.F. Perrin, B. Wursig and J.G.M. Thewissen(eds.). Academic Press, San Diego. P.770-773.

Morris PJ, Johnson WR, Pisani J, Bossart GD, Adams J, Reif JS, Fair PA. 2011. Isolation of culturable microorganisms from free-ranging bottlenose dolphins (Tursiops truncatus) from the southeastern United States. Journal of Veterinary Microbiology. 148: 440-448.

Procop GW, Church DL, Hall GS, Janda WJ, Koneman EW, Schreckenberger PC, Woods GL. 2017.
Koneman's Color Atlas and Textbook of Diagnostic Microbiology. 7th ed. Philadelphia (US): Wolters Kluwer.

Quinn PJ, Carter ME, Markey B, Carter GR. 2004. Clinical Veterinary Microbiology. Ed ke-4. New York: Mosby Inc.

Rodrigues SC, Delgano JD, Dias JL, Julia LC, Miriam M. 2018. Retrospective pathological survey of pulmonary disease in free-ranging Amazon river dolphin Inia geoffrensis and tucuxi Sotalia fluviatilis. Diseases of Aquatic Organisms. DAO 131: 1-11. Inter Research Science Publisher.

Rini EP. 2012. Identifikasi Bakteri Asal Saluran Pernafasan Atas (Blowhole) Lumba-lumba Hidung Botol Indo-Pasifik (Tursiops aduncus) di Kawasan Konservasi Pantai Cahaya Kendal Jawa Tengah [skripsi]. Bogor: Fakultas Kedokteran Hewan, Institut Pertanian Bogor.

Seepaulsingh SHS. 2014. Using comparative metagenomics to determine the role of Atlantic bottlenose dolphins (Tursiops truncates) as sentinels for human respiratory health. [Tesis]. Colombia: College of Arts and Science, University of South Carolina.

Stephanie VW, Risa D, Cynthia S. 2012. Thirty year retrospektive evaluation of pneumonia in a bottle nose dolphin Tursiop truncatus population. Diseases of Aquatic Organisms. Vol:99.237-242

Streitfeld MM, Chapman GC. 1976. Staphylococcos aureus. Infection of captive dolphins (Tursiops truncatus) an oceanarium personnel. American Journal of Veterinary Res37:303-305.

Tanaka Y, Yuasa J, Baba M, Tanikawa T, Nakagawa Y, Matsuyama T. 2004. Temperature dependent bacteriostatic activity of Serratia marcescens. Journal of Environmental Microbiology. 19:236240.

Watson SV, Daniels R, Smith C. 2012. Thirty year retrospective evaluation of pneumonia in a bottlenose dolphin Tursiops truncatus population. Disease of Aquatic Organisms. 9(1): 237-242.

Yeon EO, Kwon OD.2011. Two cases of bacterial pneumonia in Bottle Nose Dolphin (Tursiop gilli) at the seoul zoo. Korea. Pakistan Journal 31(3).260-262

Yu JH, Xia ZE.2013. Bacterial infection in on Irrawaddy Dolphin (Orcaella brevirostris). J. Zoo Wildlife Medicine. 44(1). 156-158. 